J. Gen. Appl. Microbiol., 17, 383-398 (1971)

\title{
NEW SPECIES OF YEASTS \\ RESEMBLING CANDIDA KRUSEI (CAST.) BERKHOUT
}

\author{
TAKASHI NAKASE
}

Central Research Laboratories, Ajinomoto Co. Inc., Kawasaki, Japan

(Received May 13, 1971)

\begin{abstract}
Seventy-six strains of Candida krusei and allied species obtained from culture collections and newly isolated from various natural sources were studied taxonomically. The strains employed in this work were classified into 12 groups representing 14 species mainly on the basis of carbon assimilation pattern, vitamin requirement, maximum growth temperature, and guaninecytosine content in DNA. Three new species, Candida citrea, Candida sorboxylosa, and Candida rugopelliculosa, were described.
\end{abstract}

Through the investigation on wild yeasts in Japan, many strains of Candida krusei (CAST.) BERKHOUT and its related species were isolated from various natural sources. Of these, 9 strains were found to be hitherto undescribed yeasts and to be classified into 3 species. This paper deals with a comparison of characteristics of $C$. krusei and its related yeasts, and with the descriptions of 3 new species of Candida.

\section{MATERIALS AND METHODS}

Microorganisms. Of the 76 strains examined, 26 were obtained from culture collections or investigators. The remaining 50 strains were isolated by the present author from various natural habitats. Source of cultures is listed in Table 1.

Determinative method. Determinative methods were mainly those described by WICKERHAM (1), LODDER and KREGER-VAN RIJ (2), and by KREGER-VAN RIJ (3). Macromorphology was investigated as follows: The appearance of giant colonies grown on Yeast Morphology Agar (Difco) was examined after 2 weeks' incubation at $25^{\circ}$. In this experiment, one of the colonies was covered with a sterilized cover slip in order to test its anaerobic growth. Pellicle formation was confirmed in yeast-peptone broth consisting of yeast extract (Difco), $0.5 \%$; peptone (Difco), $0.75 \%$; glucose, $1 \% ; \mathrm{pH} 6.2$. Tests of assimilation and fermentation were carried out for 5 weeks according to the procedures reported by Wickerham (1). Urease was detected by the 
Table 1. Strains employed.

\begin{tabular}{|c|c|c|}
\hline Species identified & Strain & Source \\
\hline Pichia fermentans & AJ 4458 & C. krusei var. transitoria A-1257 (H. Saëz) \\
\hline "I & AJ 4891 & convenience food \\
\hline Pichia kluyveri & AJ 4139 & beer \\
\hline$\prime \prime$ & AJ 4145 & P. fermentans ATCC 9768 \\
\hline$\prime \prime$ & AJ 4426 & banana \\
\hline "1 & AJ 4428 & "1 \\
\hline "1 & AJ 4434 & fruit of Pyrus simonii Carr. \\
\hline "1 & AJ 4440 & banana \\
\hline "1 & AJ 4444 & broad bean \\
\hline "1 & AJ 4445 & pimento \\
\hline "1 & AJ 4450 & tomato \\
\hline "l & AJ 4451 & "1 \\
\hline "1 & AJ 4455 & banana \\
\hline$\prime \prime$ & AJ 4464 & C. krusei NRRL Y-1734 \\
\hline "I & AJ 4465 & C. krusei NRRL Y-1735 \\
\hline Pichia kudriavzevii & AJ 4146 & CBS 5147 \\
\hline Pichia terricola & AJ 4137 & IFO 0933 \\
\hline Candida citrea & AJ 4441 & banana \\
\hline "1 & AJ 4769 & lemon \\
\hline "1 & AJ 4770 & "I \\
\hline Candida rugopelliculosa & AJ 4656 & soybean protein factory \\
\hline Candida sorboxylosa & AJ 4437 & pineapple \\
\hline "l & AJ 4439 & banana \\
\hline$" 1$ & AJ 4897 & artificial diet for silkworm \\
\hline "1 & AJ 4899 & "1 \\
\hline "1 & AJ 4901 & "I \\
\hline Candida sp. & AJ 4913 & moss \\
\hline Candida diversa & AJ 4648 & C. fimetaria var. diversa $\mathrm{K}-14$ (H. Nonomura) \\
\hline Candida krusei & AJ 4421 & IFO 0011 \\
\hline "1 & AJ 4422 & IFO 1063 \\
\hline "1 & AJ 4423 & WF-16 (S. Goto) \\
\hline "1 & AJ 4427 & banana \\
\hline "l & AJ 4433 & fruit of Pyrus simonii Carr. \\
\hline "1 & AJ 4457 & ATCC 6258 \\
\hline "l & AJ 4467 & soybean protein factory \\
\hline "l & AJ 4649 & "1 \\
\hline "l & AJ 4650 & "l \\
\hline "l & AJ 4652 & "1 \\
\hline "1 & AJ 4653 & "l \\
\hline
\end{tabular}


Table 1. (continued)

\begin{tabular}{|c|c|c|}
\hline Species identified & Strain & Source \\
\hline Candida krusei & AJ 4654 & soybean protein factory \\
\hline "1 & AJ 4655 & onion \\
\hline "1 & AJ 4658 & C. pseudotropicalis IFO 0586 \\
\hline "1 & AJ 4768 & C. sorbosa CCY 29-55-1 \\
\hline "I & AJ 4773 & C. tamarindii CBS 2457 \\
\hline "1 & AJ 4813 & Schizoblastosporion starkeyi-henricii ATCC 4673 \\
\hline "1 & AJ 4906 & artificial diet for silk worm \\
\hline "1 & AJ 4907 & $\prime \prime$ \\
\hline "l & AJ 4934 & Mycoderma mandshrica (FERM) \\
\hline "1 & AJ 4935 & Mycoderma monosum (FERM) \\
\hline Candida lambica & AJ 4424 & lemon \\
\hline 11 & AJ 4425 & 11 \\
\hline$\prime \prime$ & AJ 4429 & fruit of Pyrus simonii Carr. \\
\hline "l & AJ 4430 & strawberry \\
\hline "l & AJ 4431 & Chinese citron \\
\hline "1 & AJ 4432 & apple \\
\hline 11 & AJ 4436 & fruit of Pyrus simonii Carr. \\
\hline 11 & AJ 4442 & banana \\
\hline "l & AJ 4443 & strawberry \\
\hline "1 & AJ 4446 & eggplant \\
\hline "1 & AJ 4447 & garden pea \\
\hline 11 & AJ 4448 & "l \\
\hline "l & AJ 4449 & "1 \\
\hline " & AJ 4452 & "I \\
\hline "l & AJ 4453 & $\prime \prime$ \\
\hline$" 1$ & AJ 4454 & tomato \\
\hline "1 & AJ 4456 & apple \\
\hline "1 & AJ 4459 & C. krusei var. transitoria A-1426 (H. Saëz) \\
\hline$\prime \prime$ & AJ 4461 & C. monosa ATCC 2146 \\
\hline "l & AJ 4462 & C. monosa ATCC 9330 \\
\hline "1 & AJ 4647 & C. fimetaria NI 7631 \\
\hline$\prime \prime$ & AJ 4893 & convenience food \\
\hline Candida norvegensis & AJ 4675 & C. trigonopsoides IFO 0970 \\
\hline$\prime \prime$ & AJ 5003 & C. trigonopsoides CBS 1911 \\
\hline Candida santamariae & AJ 4466 & C. krusei var. saccharicola CBS 4515 \\
\hline Candida sorbosa & AJ 4463 & NRRL Y-1731 \\
\hline$\prime \prime$ & AJ 4771 & C. obtusa CCY 29-60-1 \\
\hline
\end{tabular}


Table 2. Characterization of new

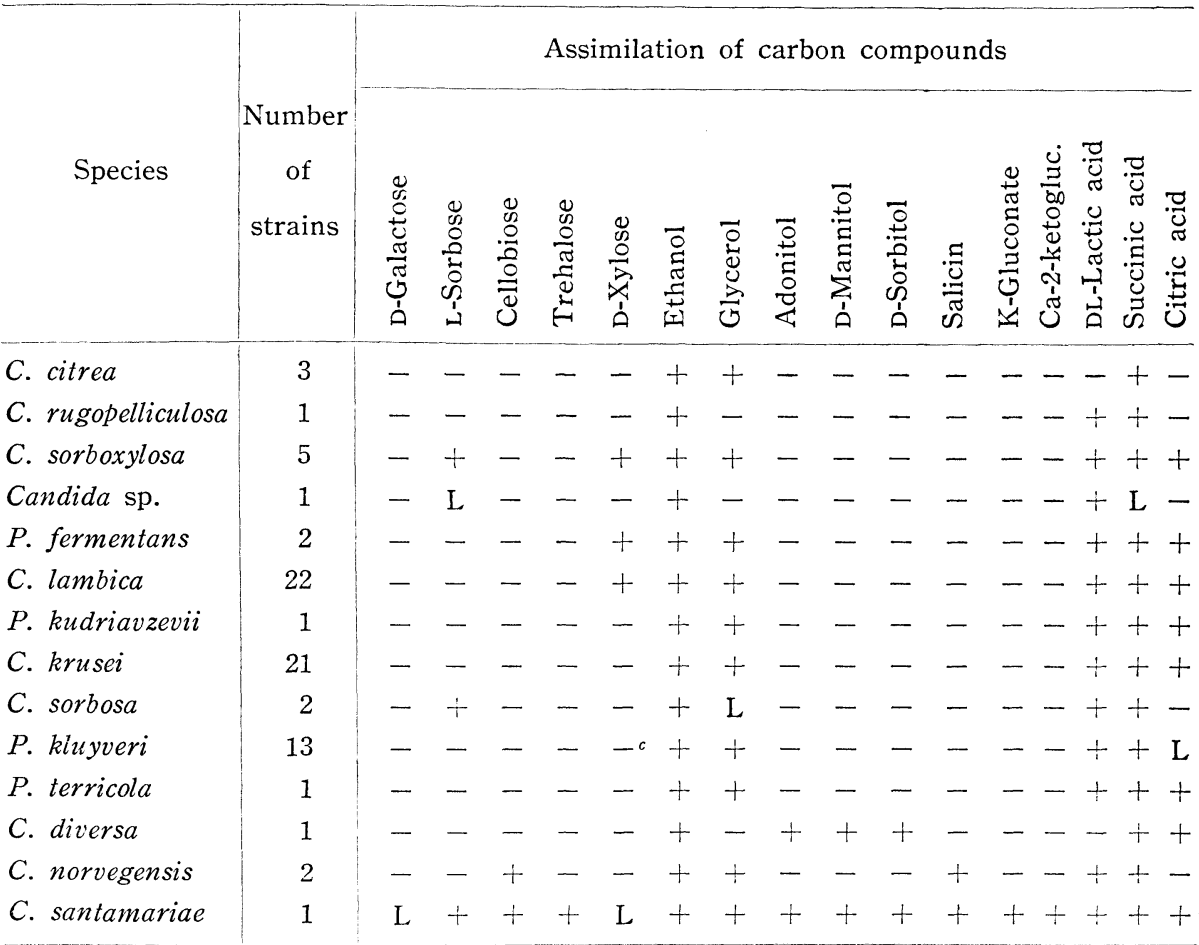

L: Latent

a B: Biotin, P: Pyridoxine, T: Thiamine, Nil: Not required.

method reported by SEELIGER (4). Methods for the determination of maximum growth temperature and requirement of vitamins were those previously described (5).

Determination of DNA base composition. DNAs were isolated and purified by the procedures described previously (6). The DNA base composition (GC content) was calculated from thermal denaturation temperature ( $\mathrm{Tm}$ ) of DNA according to the procedure of MARMUR and DOTY (7) using the formula of $\mathrm{Tm}=69.3+0.41$ (GC content). Tm was measured by the apparatus described by YAMADA and KOMAGATA $(8)$.

\section{RESULTS AND DISCUSSION}

The yeasts examined here were classified into 14 species mainly on the basis of carbon assimilation pattern, requirement of vitamins, maximum growth temperature, and GC content in DNA (Tables 2 and 3). Formation of an ester, splitting of arbutin, pellicle formation, and appearance of giant 
Candida and resembling yeasts.

\begin{tabular}{|c|c|c|c|c|c|c|c|}
\hline \multicolumn{2}{|c|}{ GC content in DNA } & \multirow[b]{2}{*}{ 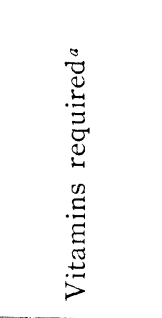 } & \multirow[b]{2}{*}{ 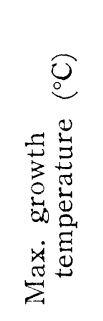 } & \multirow[b]{2}{*}{ 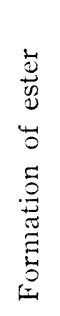 } & \multirow[b]{2}{*}{ 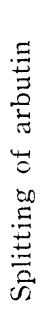 } & \multirow[b]{2}{*}{ 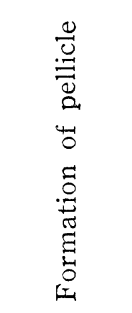 } & \multirow[b]{2}{*}{ 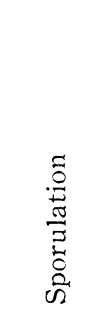 } \\
\hline & reference & & & & & & \\
\hline $32.9-33.2$ & & $\mathrm{~B}, \mathrm{~T}$ & $31-34$ & - & - & + & - \\
\hline 30.0 & & Nil & $38-39$ & - & - & + & - \\
\hline 39.8 & & $\mathrm{P}, \mathrm{T}$ & $38-39$ & - & - & + & - \\
\hline 31.2 & & Nil & $30-31$ & - & - & + & - \\
\hline 42.2 & 23 & $\mathrm{~T}$ & $38-39$ & - & - & + or - & + \\
\hline $42.7-43.2$ & 20 & $\mathrm{~T}$ & $36-40$ & - & - & + or - & - \\
\hline 38.5 & 23 & Nil & $43-44$ & - & - & + & + \\
\hline $39.0-39.3$ & 20 & $\mathrm{Nil}$ & $43-45$ & - & - & + & - \\
\hline $40.0-40.5$ & 20 & Nil & $38-40$ & - & - & + & - \\
\hline $28.3-28.5$ & 23 & $\mathrm{~B}, \mathrm{P},(\mathrm{T})^{b}$ & $36-40$ & + & - & + & + or - \\
\hline $36.6-36.8$ & 23 & $\mathrm{~T}$ & $36-37$ & - & - & + & + \\
\hline $34.4-34.9$ & 20 & $\mathrm{~B}, \mathrm{P}, \mathrm{T}$ & $36-37$ & - & - & - & - \\
\hline $35.6-36.6$ & 20 & $\mathrm{~B}, \mathrm{P}, \mathrm{T}$ & $42-43$ & - & - & - & - \\
\hline 36.3 & 20 & $\mathrm{~B}, \mathrm{~T}$ & $31-32$ & - & + & - & - \\
\hline
\end{tabular}

$b$ One strain was stimulated by thiamine.

c Some strains assimilated this sugar latently and weakly.

colonies were also taken into consideration. Fifty strains which were isolated from various sources by the present author were classified into 8 species, including 3 new species.

Generally, morphological characteristics has a limited value in the discrimination of species of this group of yeasts. However, it was useful in differentiating Pichia kudriavzevii-Candida krusei from the other species of this group. P. kudriavzevii-C. krusei group was characterized by the formation of well-developed pseudomycelium which often resembled true mycelium, and by formation of colonies with characteristic hair. These were not found in any other species dealt with in this work. In many cases, pellicle formation could be used as a criterion for delimiting species. However, developmental stage of pellicle varied from completely lacking to well developed in the case of Pichia fermentans-Candida lambica. This characteristic is considered to be minor.

The number of carbon compounds utilized by $C$. krusei and allied species was rather restricted, and only 4 to 8 out of 33 compounds were assimilated. 
Table 3. DNA base composition of new species of Candida.

\begin{tabular}{c|c|c|c}
\hline Species & Strain & $\begin{array}{c}\text { Tm } \\
\left({ }^{\circ} \mathrm{C}\right)\end{array}$ & $\begin{array}{c}\text { GC content in DNA } \\
(\text { mol. \%) }\end{array}$ \\
\hline Candida citrea & AJ 4441 & 82.9 & 33.2 \\
/" & AJ 4769 & 82.8 & 32.9 \\
Candida rugopelliculosa & AJ 4656 & 81.6 & 30.0 \\
Candida sorboxylosa & AJ 4437 & 85.6 & 39.8 \\
I" & AJ 4897 & 85.6 & 39.8 \\
Candida $\mathrm{sp.}$ & AJ 4913 & 82.1 & 31.2 \\
\hline
\end{tabular}

An exception was found in the case of Candida santamariae where 17 compounds were utilized. C. santamariae and Candida diversa were easily discriminated from the other species because they utilized adonitol, D-mannitol, and D-sorbitol. Difference in the carbon assimilation patterns of other species in this group of yeasts was not large but distinct in many cases. P. kudriavzevii-C. krusei, Pichia kluyveri, and Pichia terricola could not be discriminated from one another by their carbon assimilation patterns, and so was the case of Candida sp. AJ 4913 and Candida rugopelliculosa though a slight difference was found in the assimilation of L-sorbose (Table 2). The fermentation test of sugars could not be used for differentiation of $C$. krusei and allied species because they fermented only D-glucose out of 7 sugars tested. A considerable difference, however, was found in the rapidity of D-glucose fermentation, i.e., rapid in $P$. kudriavzevii-C. krusei, $P$. fermentans-C. lambica, $P$. kluyveri, Candida citrea, and C. rugopelliculosa, moderate in Candida sorbosa, C. santamariae, and $C$. diversa, and slow in other species. The maximum growth temperature of $C$. krusei and allied species ranged widely from 30 to $45^{\circ}$, but intraspecific variation fell within $4^{\circ}$. Therefore, this characteristic is considered to be a good taxonomic criterion. The vitamin requirement pattern was specific for each species. An exception was found in the case of $P$. kluyveri AJ 4451. This strain stimulatively required thiamine and differed from other strains of the same species. As a whole, however, this characteristic is considered to be useful for delimitation of the species. Taxonomic significance of vitamin requirement and maximum growth temperature was pointed out by VAN UDEN and FARINHA (9) and by VAN UDEN and Do CARMO SOUSA (10), and confirmed by Komagata and NAKASE (5). This was shown again in the present experiment. Arbutin was split only by C. santamariae. Ester formation was observed in $P$. kluyveri. These two characteristics are useful in discriminating these two species from the other species mentioned.

The GC content of DNA of C. krusei and allied species ranged from 28.3 to $43.2 \%$ (Tables 2 and 3). It exhibited a specific value for each species or for a pair of species (perfect and imperfect). The highest value was demonstrated by $P$. fermentans-C. lambica $(42.2-43.2 \%)$, followed by $C$. sorbosa 
(40.0-40.5\%), Candida sorboxylosa (39.8\%), P. kudriavzevii-C. krusei (38.5$39.3 \%)$, P. terricola (36.6-36.8\%), C. santamariae (36.3\%), Candida norvegensis (35.6-36.6\%), C. diversa (34.4-34.9\%), Candida citrea (32.9-33.2\%), Candida sp. AJ 4913 (31.2\%), C. rugopelliculosa (30.0\%), and P. kluyveri (28.3-28.5\%). The DNA base composition is considered to be one of the basic characteristics for elucidating a taxonomic and phylogenetic relationship among microorganisms. It is especially useful when only a minor difference can be found between two yeasts as found in the present experiment; for example, $C$. sorbosa and Candida sp. AJ 4913 exhibited a minor difference in taxonomic criteria commonly employed in spite of about $9 \%$ difference in the GC content as shown in Table 2.

1. Candida citrea NAKASE sp. nov.

Strains: See Table 1.

Cellulae in agaro subovoideae, ovoideae, long ovoideae, $(2-6.5) \times(2.5-15) \mu$, singulae, binae aut catenatae. Anulus formatur. Cultura in agaro (post duae septimanae, $25^{\circ}$ ) subbrunnea, glabra, mollis, margine glabra. Pseudomycelium formatur. D-Glucosum fermentatur at non D-galactosum, saccharosum, maltosum, lactosum, raffinosum nec melibiosum. In medio minerali D-glucosum, ethanolum, glycerolum et acidum succinicum assimilantur at non D-galactosum, saccharosum, maltosum, lactosum, L-sorbosum, cellobiosum, trehalosum, melibiosum, raffinosum, melezitosum, inulinum, amylum, D-xylosum, L-arabinosum, D-arabinosum, D-ribosum, L-rhamnosum, erythritolum, adonitolum, dulcitolum, D-mannitolum, D-sorbitolum, $\alpha$-methyl-D-glucosidum, salicinum, potassium gluconatum, calcium 2-ketogluconatum, acidum DL-lacticum, acidum citricum nec inositolum. Nitras kalicus non assimilatur. Arbutinum non finditur. Biotinae et thiaminae necessariae ad crescentiam. Maxima temperatura crescentiar: $31-34^{\circ}$.

Cells on Yeast Morphology Agar: After 3 days at $25^{\circ}$, cells are short oval, oval to long oval, $(2-6.5) \times(2.5-15) \mu$, and occur singly, in pairs or in small groups.

Pellicle formation in yeast-peptone broth: A thin, smooth and incomplete pellicle is formed.

Giant colony on Yeast Morphology Agar: The colony is pale yellow to pale brown, smooth or slightly wrinkled, mat, soft to butyrous and has an entire margin.

Dalmau plate culture on potato dextrose agar: Pseudomycelia are rather rudiment. Blastospores are short oval to oval or elongate, and occur in verticils.

Fermentation: D-Glucose is rapidly fermented. D-Galactose, saccharose, maltose, lactose, raffinose, and melibiose are not fermented.

Assimilation of carbon compounds: D-Glucose, ethanol, glycerol, and succinic acid are assimilated. D-Galactose, saccharose, maltose, lactose, Lsorbose, cellobiose, trehalose, melibiose, raffinose, melezitose, inulin, soluble 


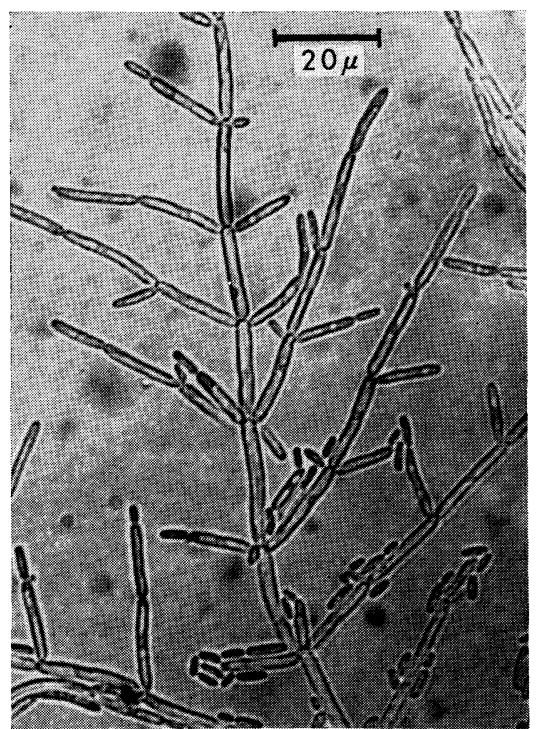

Fig. 1. Pseudomycelia of Candida citrea AJ 4441, Dalmau plate culture on potato-dextrose agar for 7 days at $25^{\circ}$.

starch, D-xylose, L-arabinose, D-arabinose, D-ribose, L-rhamnose, erythritol, adonitol, dulcitol, D-mannitol, D-sorbitol, $\alpha$-methyl-D-glucoside, salicin, potassium gluconate, calcium 2-ketogluconate, DL-lactic acid, citric acid, and inositol are not assimilated.

Potassium nitrate is not utilized as the sole nitrogen source.

Arbutin is not splitted.

Biotin and thiamine are required at $25^{\circ}$.

Maximum growth temperature is $31-34^{\circ}$.

Gelatin is not liquefied.

Urease is not detected.

The GC content of DNA of $C$. citrea was similar to those of $C$. diversa and Candida sp. AJ 4913. Since $C$. diversa assimilates adonitol, D-mannitol, and D-sorbitol, C. citrea is clearly discriminated from this species in this point. Although a difference between C. citrea and Candida sp. AJ 4913 is rather small, they are differentiated from each other by the following characteristics: C. citrea assimilates glycerol but not L-sorbose or DL-lactic acid, and requires biotin and thiamine, while Candida sp. AJ 4913 assimilates L-sorbose (latent) and DL-lactic acid but not glycerol, and requires no vitamin. $C$. rugopelliculosa also resembled $C$. citrea but GC content of these two species differed by about 3\% (Table 3). C. citrea, C. rugopelliculosa, and Candida sp. AJ 4913 are similar to one another not only in taxonomic criteria com- 
monly employed but also in the GC content, and are assumed to be closely related to one another. The present author dealt with these yeasts as separate species, because C. krusei and its taxonomically related yeasts examined in the present experiment often exhibited considerable difference in the GC content in spite of a close similarity in taxonomic criteria commonly employed. It is considered that the small differences found in carbon assimilation pattern, maximum growth temperature, and vitamin requirement should not be neglected in yeasts which utilize only a restricted number of carbon compounds.

Since this yeast was first isolated from lemon, the specific epithet "citrea" was given. Strain AJ 4769 is the type strain of this species.

\section{Candida rugopelliculosa NAKASE sp. nov.}

Strain: See Table 1.

Cellulae in agaro ovoideae, long ovoideae aut longae, $(2-5) \times(2.5-10) \mu$, vulgo catenatae. Pellicula rugosa formatur. Cultura in agaro (post duae septimanae, $25^{\circ}$ ) subbrunnea, rugosa. Pseudomycelium formatur. D-Glucosum fermentatur at non D-galactosum, saccharosum, maltosum, lactosum, raffinosum nec melibiosum. D-Glucosum, ethanolum, acidum DL-lacticum et acidum succinicum assimilantur at non D-galactosum, saccharosum, maltosum, lactosum, L-sorbosum, cellobiosum, trehalosum, melibiosum, raffinosum, melezitosum, inulinum, amylum, D-xylosum, L-arabinosum, D-arabinosum, D-ribosum, Lrhamnosum, glycerolum, erythritolum, adonitolum, dulcitolum, D-mannitolum, D-sorbitolum, $\alpha$-methyl-D-glucosidum, salicinum, potassium gluconatum, calcium 2-ketogluconatum, acidum citricum nec inositolum. Nitras kalicus non assimilatur. Arbutinum non finditur. Vitaminae externae non necessariae ad crescentiam. Maxima temperatura crescentiar: $38-39^{\circ}$.

Cells on Yeast Morphology Agar: After 3 days at $25^{\circ}$, cells are oval, long oval, sometimes elongate, $(2-5) \times(2.5-10) \mu$, and usually occur in chains.

Pellicle formation in yeast-peptone broth: A thick, strongly wrinkled and highly creeping pellicle is rapidly formed. It is yellowish white to pale brown.

Giant colony on Yeast Morphology Agar: The colony is white to pale brown, dry, butyrous, and delicately wrinkled all over the surface, and has an erose margin.

Dalmau plate culture on potato dextrose agar: Well-developed pseudomycelia are abundantly formed. They are tree-like.

Fermentation: D-Glucose is rapidly fermented. D-Galactose, saccharose, maltose, lactose, raffinose, and melibiose are not fermented.

Assimilation of carbon compounds: D-Glucose, ethanol, DL-lactic acid, and succinic acid are assimilated. D-Galactose, saccharose, maltose, lactose, L-sorbose, cellobiose, trehalose, melibiose, raffinose, melezitose, inulin, soluble starch, D-xylose, L-arabinose, D-arabinose, D-ribose, L-rhamnose, glycerol, erythritol, adonitol, dulcitol, D-mannitol, D-sorbitol, $\alpha$-methyl-D-glucoside, sali- 


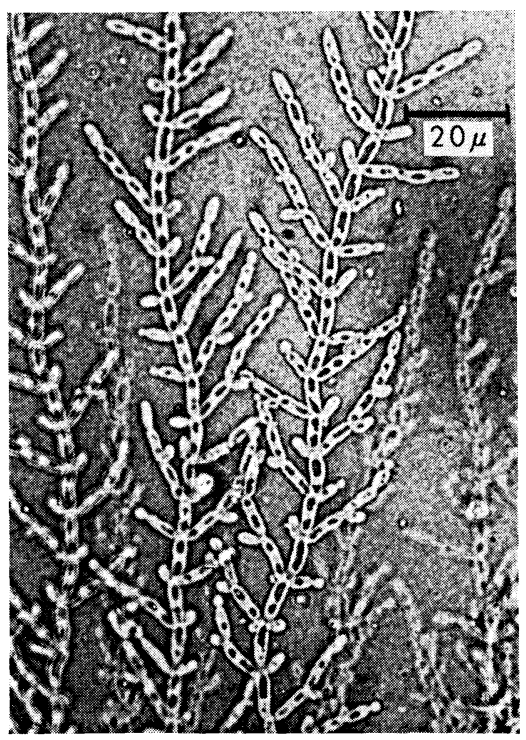

Fig. 2. Pseudomycelia of Candida rugopelliculosa AJ 4656, Dalmau plate culture on potato-dextrose agar for 7 days at $25^{\circ}$.

cin, potassium gluconate, calcium 2-ketogluconate, citric acid, and inositol are not assimilated.

Potassium nitrate is not utilized as the sole nitrozen source.

Arbutin is not splitted.

Vitamin is not required at $25^{\circ}$.

Maximum growth temperature is $38-39^{\circ}$.

Gelatin is not liquefied.

Urease is not detected.

C. rugopelliculosa resembles C. krusei in many points though $\mathrm{GC}$ values of DNA of these two yeasts are quite different, i.e., $30.0 \%$ for the former and $39.0-39.3 \%$ for the latter. Practicably, these two species are discriminated from each other in the following characteristics: C. rugopelliculosa assimilates neither glycerol nor citric acid, and exhibits a maximum growth temperature of $38-39^{\circ}$, while, C. krusei assimilates glycerol and citric acid, and exhibits a maximum growth temperature of $43-45^{\circ}$. Furthermore, C. krusei exhibits morphological differences as already mentioned. Since this yeast forms a characteristic rugose pellicle, the specific epithet "rugopelliculosa" was given. Strain AJ 4656 is the type strain of this species.

3. Candida sorboxylosa NAKASE sp. nov.

Strains: See Table 1.

Cellulae in agaro subovoideae, ovoideae, long ovoideae aut longae, $(2-6) \times$ 
(2.5-11-20) $\mu$, singulae, binae aut catenatae. Anulus formatur. Cultura in agaro (post duae septimanae, $25^{\circ}$ ) subflava, glabra, mollis, margine glabra. Pseudomycelium formatur. D-Glucosum fermentatur at non D-galactosum, saccharosum, maltosum, lactosum, raffinosum nec melibiosum. D-Glucosum, L-sorbosum, D-xylosum, ethanolum, glycerolum, acidum DL-lacticum, acidum succinicum et acidum citricum assimilantur at non D-galactosum, saccharosum, maltosum, lactosum, cellobiosum, trehalosum, melibiosum, melezitosum, inulinum, amylum, L-arabinosum, D-arabinosum, D-ribosum, L-rhamnosum, erythritolum, adonitolum, dulcitolum, D-mannitolum, D-sorbitolum, $\alpha$-methyl-Dglucosidum, salicinum, potassium gluconatum, calcium 2-ketogluconatum nec inositolum. Nitras kalicus non assimilatur. Arbutinum non finditur. Pyridoxinae et thiaminae necessariae ad crescentiam. Maxima temperatura crescentiar: $37-39^{\circ}$.

Cells on Yeast Morphology Agar: After 3 days at $25^{\circ}$, cells are short oval to long oval or elongate, $(2-6) \times(2.5-11-20) \mu$, and occur singly, in pairs, or in chains.

Pellicle formation in yeast-peptone broth: A thin, smooth, and creeping pellicle is formed. It is often incomplete.

Giant colony on Yeast Morphology Agar: The colony is pale yellow, smooth, dull, soft to butyrous, and has an entire margin.

Dalmau plate culture on potato dextrose agar: Usually, pseudomycelia are tree-like. The developmental stage is different in various strains.

Fermentation: D-Glucose is slowly fermented. D-Galactose, saccharose, maltose, lactose, raffinose, and melibiose are not fermented.

Assimilation of carbon compounds : D-Glucose, L-sorbose, D-xylose, ethanol, glycerol, DL-lactic acid, succinic acid, and citric acid are assimilated. DGalactose, saccharose, maltose, lactose, cellobiose, trehalose, melibiose, melezitose, inulin, soluble starch, L-arabinose, D-arabinose, D-ribose, L-rhamnose, erythritol, adonitol, dulcitol, D-mannitol, D-sorbitol $\alpha$-methyl-D-glucoside, salicin, potassium gluconate, calcium 2-ketogluconate, and inositol are not assimilated.

Potassium nitrate is not utilized as the sole nitrogen source.

Arbutin is not splitted.

Pyridoxine and thiamine are required at $25^{\circ}$.

Maximum growth temperature is $37-39^{\circ}$.

Gelatin is not liquefied.

Urease is not detected.

Since this species is characterized by assimilation of L-sorbose and Dxylose, it is easily discriminated from the other species dealt with in this paper. Another yeast which assimilates L-sorbose and D-xylose, C. santamariae, is quite different from $C$. sorboxylosa in its carbon assimilation pattern as shown in Table 2. The specific epithet "sorboxylosa" represents its differential characteristic. Strain AJ 4437 is the type strain of this species. 


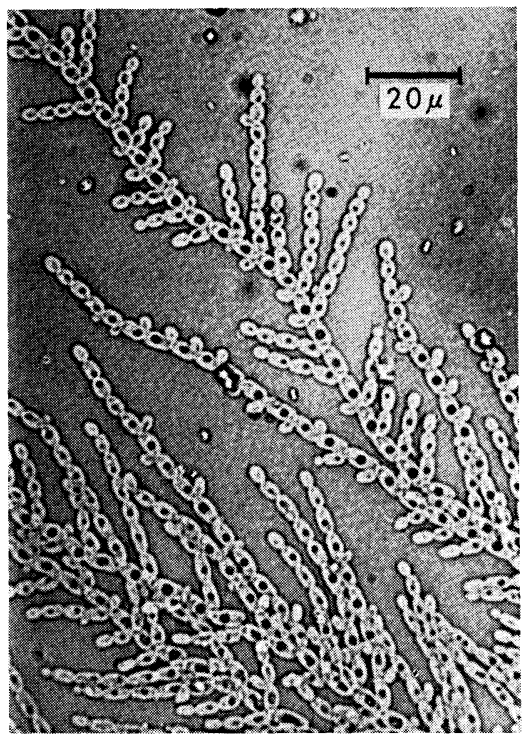

Fig. 3. Pseudomycelia of Candida sorboxylosa AJ 4437, Dalmau plate culture on potato-dextrose agar for 7 days at $25^{\circ}$.

\section{Candida sp. AJ 4913}

Cells on Yeast Morphology Agar: After 3 days at $25^{\circ}$, cells are round, short oval to oval, $(2-7.5) \times(2-8) \mu$, and occur singly, in pairs or in chains.

Pellicle formation in yeast-peptone broth: A thin, white, smooth, and creeping pellicle is formed.

Giant colony on Yeast Morphology Agar: The colony is pale yellow, smooth, dull, soft, and has an entire or erose margin. Wrinkled sectors often develop from a smooth colony.

Dalmau plate culture on potato dextrose agar: Pseudomycelia develop abundantly. Blastospores are round or oval, and occur singly, in pairs, in clusters or in verticils.

Fermentation: D-Glucose is slowly fermented. D-Galactose, saccharose, maltose, lactose, raffinose, and melibiose are not fermented.

Assimilation of carbon compounds: D-Glucose, L-sorbose (latent), ethanol, DL-lactic acid, and succinic acid (latent) are assimilated. D-Galactose, saccharose, maltose, lactose, cellobiose, trehalose, melibiose, raffinose, melezitose, inulin, soluble starch, D-xylose, L-arabinose, D-arabinose, D-ribose, L-rhamnose, glycerol, erythritol, adonitol, dulcitol, D-mannitol, D-sorbitol, $\alpha$-methyl-Dglucoside, salicin, potassium gluconate, calcium 2-ketogluconate, citric acid, and inositol are not assimilated.

Potassium nitrate is not utilized as the sole nitrogen source.

Arbutin is not splitted. 


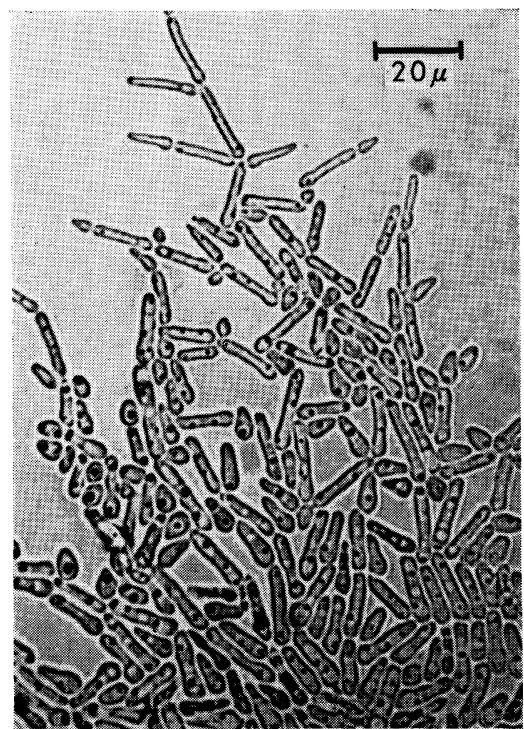

Fig. 4. Pseudomycelia of Candida sp. AJ 4913, Dalmau plate culture on potato-dextrose agar for 7 days at $25^{\circ}$.

Vitamin is not required at $25^{\circ}$.

Maximum growth temperature is $30-31^{\circ}$.

Gelatin is not liquefied.

Urease is not detected.

This yeast resembles $C$. rugopelliculos $a$ in many respects but differed from the latter yeast in assimilation of L-sorbose, maximum growth temperature, and appearance of the colony. The present author hesitates in dealing with this yeast as a separate species from $C$. rugopelliculosa since the difference mentioned above is very small. Therefore, it was decided to retain this yeast unnamed until a more distinct difference is found between these two yeasts.

\section{Pichia fermentans LODDER}

Imperfect form: Candida lambica (LINDNER et GENOUd) VAN UDEN et BUCKLEY

Strains: See Table 1.

Two strains of $P$. fermentans and 22 strains of $C$. lambica agreed well with the standard descriptions $(11,12)$. The only exception was found in assimilation of citric acid which was positive in the present experiment.

6. Pichia kudriavzevii BoIdin, PIGNal et BESSON

Imperfect form: Candida krusei (CAST.) BERKHOUT

Strains: See Table 1. 
The present work did not confirm MonTROCHER's finding (13) that $C$. krusei assimilated adonitol, D-xylose, D-ribose, and saccharose, and required vitamins, but agreed with the results of VAN UDEN and BUCKLEY (12) with one exception, i.e., assimilation of citric acid which was positive in the present experiment. Some strains of this species formed relatively smooth colonies, and many others much wrinkled ones. In both cases, distinct fine hairs were observed on the surface of aged colonies. This was not found in any other species dealt with in this paper. True mycelium formation in C. krusei reported by ETCHELlS and BELL (14), and by HEDRICK and BURKE (15) was not confirmed in the present experiment, but pseudomycelia of this species often resembled true mycelia. Schizoblastosporion starkeyi-henricii ATCC 4673 (AJ 4813) exhibited the typical characteristics of C. krusei. This strain is now considered to have been mislabeled $(2,16)$. C. sorbosa CCY 29-55-1 (AJ 4768) and C. pseudotropicalis IFO 0586 (AJ 4658) are also considered to have been mislabeled. C. tamarindii CBS 2457 (AJ 4773) did not correspond to the original description (17). MONTROCHER (13) reported that C. tamarindii and $C$. krusei could be discriminated by assimilation of adonitol and D-xylose, and requirement of vitamins. In the present experiment, however, these two species assimilated neither adonitol nor D-xylose, and required no vitamin. C. tamarindii is a synonym of $C$. krusei as considered by VAN UDEN and BuCKLEY (12).

TSUCHIYA et al. (18) described a new yeast, Pichia krusei, and regarded it as the perfect form of $C$. krusei on the basis of serological characteristics. This species, however, is not considered as the perfect form of C. krusei because these two species differ in the assimilation of trehalose, adonitol, Dmannitol, D-sorbitol, DL-lactic acid, and citric acid, though GC values in DNA of these two species are similar to each other $(19,20)$.

\section{Candida sorbosa HEDRICK et BURKE ex VAN UdEN et BUCKLEY}

Strains: See Table 1.

Two strains showed the same characteristics as those in the standard description of this species (12) except assimilation of succinic acid in the present experiment. The one labeled C. obtusa CCY 29-60-1 (AJ 4771) showed the typical characteristics of $C$. sorbosa and was considered to have been mislabeled.

\section{Pichia kluyveri BEDFORD}

Strains: See Table 1.

Thirteen strains examined agreed well with the standard description by Kreger-VAN RIJ (11). This species resembles $P$. fermentans in taxonomic criteria commonly employed but is considered to be a quite different species from the latter because GC content of this species is much lower than that of $P$. fermentans (Table 2). DE CARMAGo and PhAFF (21) and KREGER-VAN RIJ $(3,11)$ reported that this species cannot utilize D-xylose. Meanwhile, 
PIGNAL and BoIDIN (22) observed a good assimilation of D-xylose by $P$. kluyveri after several weeks' incubation. In the present experiment, some strains weakly assimilated this sugar after 5 weeks' incubation.

\section{Pichia terricola VAN DER WALT}

Strain: See Table 1.

The strain agreed well with the standard description by KREGER-VAN RIJ (11).

10. Candida diversa OHARA, Nonomura et YunOme ex VAN Uden et BUCKLEY

Strain: See Table 1.

The strain employed agreed well with the standard description except for assimilation of succinic acid and citric acid. The latter two compounds were assimilated in the present experiment.

\section{Candida norvegensis (DIETRICHSON) VAN UDEN et FARINHA ex VAN UDEN et BUCKLEY}

Strain: See Table 1.

Two strains originally labeled as $C$. trigonopsoides agreed well with the standard description by VAN UDEN and BUCKLEY (12). C. trigonopsoides is considered to be a synonym of $C$. norvegensis as considered by these authors.

\section{Candida santamariae MonTrocher}

Strain: See Table 1.

Differing from the standard description by VAN UDEN and BUCKLEY (12), this species assimilated cellobiose, D-xylose (latent), and salicin, and agreed with the result of MONTROCHER (13) in this point.

The cultures derived from Candida citrea AJ 4769, Candida rugopelliculosa AJ 4656, and Candida sorboxylosa AJ 4437 have been deposited in the Institute for Fermentation, Osaka (IFO), and registered as IFO 1572, 1577, and 1578, respectively.

The author thanks Dr. K. Komagata for his invaluable comments in this work. Many thanks are also due to Drs. H. Nonomura, L.J. Wickerham, A. Kocková-Kratochvílová, S. Goto, M. Soneda, and H. Saëz who supplied the author some of the strains, and to Mrs. M. Simmyo, Mrs. H. Shiobara, and Miss S. Miyazawa for technical assistance.

\section{REFERENCES}

1) L.J. Wickerham, Taxonomy of Yeasts, U.S.D.A. Tech. Bull., No. 1029 (1951).

2) J. Lodder and N.J.W. Kreger-VAN RiJ, The Yeasts, a Taxonomic Study, NorthHolland Publ. Co., Amsterdam (1952). 
3) N.J.W. Kreger-VAn RiJ, A Taxonomic Study of the Yeast Genera Endomycopsis, Pichia and Debaryomyces, thesis, Leiden University (1964).

4) H.P.R. Seeliger, J. Bacteriol., 72, 127 (1956).

5) K. Komagata and T. NAKAse, Shokuhin Eiseigaku Zasshi, 8, 53 (1967).

6) T. Nakase and K. Komagata, J. Gen. Appl. Microbiol., 14, 345 (1968).

7) J. MARMur and P. Doty, J. Mol. Biol., 5, 109 (1962).

8) K. Yamada and K. Komagata, J. Gen. Appl. Microbiol., 16, 215 (1970).

9) N. Van Uden and M. Farinha, Port. Acta Biol. (B), 6, 161 (1958).

10) N. van Uden and L. Do Carmo Sousa, Port. Acta Biol. (B), 6, 239 (1959).

11) N.J.W. Kreger-van Rij, Genus Pichia Hansen, in The Yeasts, a Taxonomic Study, ed. by J. Lodder, North-Holland Publ. Co., Amsterdam (1970).

12) N. van Uden and H. Buckley, Genus Candida Berkhout, In The Yeasts, a Taxonomic Study, ed. by J. Lodder, North-Holland Publ. Co., Amsterdam (1970).

13) R. Montrocher, Bull. Soc. Mycol. France, 83, 641 (1967).

14) J.L. Etchells and T.A. Bell, Food Technol., 4, 77 (1950).

15) L.R. Hedrick and G.C. Burke, Mycopathol. Mycol. Appl., 6, 92 (1951).

16) M.E. DI Menna, Mycopathol. Mycol. Appl., 25, 205 (1965).

17) Y.S. LEWIS and D.S. JOHAR, Science and Culture, 21, 220 (1955).

18) T. Tsuchiya, Y. Fukazawa, T. Shinoda, and M. Imai, Japan. J. Exp. Med., 37, 285 (1967).

19) T. Nakase and K. Komagata, J. Gen. Appl. Microbiol., 17, 227 (1971).

20) T. Nakase and K. Komagata, J. Gen. Appl. Microbiol., 17, 259 (1971).

21) R. De Carmago and H.J. Phaff, Food Res., 22, 367 (1957).

22) M.C. Pignal and J. Boidin, Bull. Soc. Mycol. France, 81, 197 (1965).

23) T. Nakase and K. Komagata, J. Gen. Appl. Microbiol., 16, 511 (1970). 